\title{
Modification OF SYllabi at THE FACUlTy OF ECONOMICS, TeChNiCAL UNIVERSITY OF LIBEREC DURING ONLINE TEACHING CAUSED BY THE PANDEMic - Questionnaire Survey Results
}

\author{
Šárka Hastrdlová \\ Technical University of Liberec, Faculty of Economics, Department of Foreign Languages, \\ Studentská 1402/2, 46117 Liberec 1, Czech Republic \\ e-mail: $\underline{\text { sarka.hastrdlova@tul.cz }}$
}

\begin{abstract}
The article summarizes a qualitative and quantitative analysis of the results of a questionnaire survey that took place at the Faculty of Economics, Technical University of Liberec in May 2021. The exceptional situation that occurred during the coronavirus pandemic forced all academic personnel to transfer their teaching to online platforms. Obviously, such a shift caused changes not only in the nature of teaching and syllabi but also in communication with students as well as the relations between students and academic workers. The main goal of this research was to find out how — or whether - the teachers modified their syllabi, or course plans, and adapted them to teaching in the online environment, and to what extent. The questionnaire further examined the teachers' views on online teaching, its negative and positive aspects, and the tools that the academic workers have used most or least in online teaching. The research results primarily map the current situation at the Faculty of Economics and bring a reflection concerning other possibilities that online teaching offers and, of course, concerning also its pitfalls.
\end{abstract}

\section{Keywords}

Academic workers; Questionnaire survey; Quantitative and qualitative analysis; Syllabus modifications; Online teaching; Pandemic.

\section{Introduction}

The coronavirus pandemic has had a considerable impact on most sectors and industries globally including the academic world. Millions of learners and teachers had to stay at home continuing the process of learning and teaching in an online mode [1]. Therefore, the complete lockdown led the Technical University of Liberec to introduce online classes in September 2020 to ensure continuity of education for its university students. As a result, all academic workers had to abandon their well-established teaching practises and modify their lectures and seminars accordingly to comply with the established syllabus online.

Online learning varies from traditional classroom settings fundamentally, even more, when the students' motivation and teacher-student interaction and feedback come into play [2]. This unprecedented shift from face-to-face to online teaching and learning environment was so vast and remarkable that creating a questionnaire survey for the academic workers regarding their experience with one year of online teaching seemed to be a natural step. Worldwide, only a few studies aiming to understand how this unique situation, i.e., online classes, worked for teachers and students have been carried out so far.

It should be apparent that, especially for online classrooms courses, the syllabus is the skeleton that formulates the course. It lays out the schedule, requirements, and activities of the 
whole course. It is the place where learners can find all the requirements of the course. The syllabus may be lengthy, but it should be clearly organized, thorough and detailed [3]. However, the online syllabus should not be so lengthy that it intimidates and overwhelms the online students. On the other hand, it can be difficult to foresee all issues to include in a syllabus before the online course begins [4].

The article brings a short overview of the most significant outcomes of the presented questionnaire survey. The questionnaire was created for the academic workers at one of the faculties of the Technical University of Liberec, the Faculty of Economics. It aimed not only to see how the teachers modified their teaching plans and syllabi, but also it included questions enquiring about their experience, feelings, and attitude to online teaching as such. The questionnaire collected primary data. Finally, it is necessary to note that the survey presented is far from exhaustive [5]. There is no doubt that further research on the specificity of online teaching and learning will have to continue.

\section{$1 \quad$ Methodology}

The primary aim of the presented questionnaire survey was to find the academic workers' experience, opinion and impact of forced online education during the coronavirus pandemic on their traditional teaching practices and mainly modification of their syllabi accordingly at the Faculty of Economics.

\subsection{Preparation of the Questionnaire}

The questionnaire contained 33 questions. In the beginning, three sorting questions were added to assess preliminary information. The detailed information is given in Section 1.2. Further questions were simple yes/no questions while other provided the respondents with the option to select multiple answers. There were also some scale questions (scale from 0-5) and open questions where the teachers could give their own opinion.

The questionnaire focused on the following three areas:

a) Syllabus modifications for the purposes of online teaching. How the online syllabus varies from their standard syllabus for face-to-face teaching - efficient and inefficient teaching tools,

b) Teacher - student online class interaction,

c) Attitude of the teachers towards online teaching - feelings and opinions.

As it was mentioned above, the questionnaire was prepared to focus on the faculty academic workers only.

\subsection{Data Collection and Analysis}

Seven departments including the Department of Foreign Languages at the Faculty of Economics were addressed to complete the questionnaire within the scope of two weeks from 26 April to 7 May 2021 as the so-called two-stage survey. The questionnaire was circulated electronically via google forms. There are 75 academic workers including $19 \mathrm{Ph} . \mathrm{D}$. students at the Faculty of Economics. In total, 58 academic workers from all departments responded and completed the questionnaire. At the beginning, three sorting questions were placed to find out more about individual respondents. These were the department they work for, their status at the faculty - a Ph.D. student or an academic worker and years of teaching experience. It appears that in the further analysis, the involvement of individual departments in responding to the questionnaire together with other aspects such as the status of a Ph.D. student at the faculty and the years of teaching experience played a significant role. Out of 58 respondents, 
there were seven Ph.D. students. As for the years of teaching experience, $76 \%$ respondents have more than eight years of teaching experience, $14 \%$ between $4-8$ years and $10 \%$ has less than four years of teaching experience. The majority of the responses were collected in an excel sheet and visualized as charts and graphs, as shown below. Open questions were compiled, studied, analysed and interpreted along with other responses the questionnaire survey revealed. One of the types of analysis applied to some responses was Cramér's V test, a statistical method that measures association between two nominal variables, giving value between 0 and +1 (inclusive). It indicates how strongly two categorical variables are associated. If the value is close to zero, it means that the two categories are not closely associated; on the other hand, if the value reaches +1 , the association is stronger. It is necessary to note that for the purposes of the article, only the most relevant and noteworthy questions and responses were selected and analysed both qualitatively and quantitatively.

\section{$2 \quad$ Results and Discussion}

In the following subsections, a more thorough analysis and discussion is provided of the three areas of concern in the questionnaire survey mentioned above.

\subsection{Syllabus Modifications for the Purposes of Online Teaching. How the Online Syllabus Varies from the Standard One for Face-to-Face Teaching - Efficient and Inefficient Teaching Tools}

Questions 4-14 targeted the syllabus modifications first in a general way and then in more detail. Primarily, it must be noted that some academic workers had trouble with the meaning and understanding of the word syllabus in the beginning. It is mainly noticeable when questions 6 and 7 are compared. When the academic workers were generally asked to what extent they had to modify their syllabus for online teaching, $28 \%$ of them stated they did not have to modify anything. However, once they had to choose from more structured options within question 7 , only $3 \%$ of the academic workers stated they did not make any changes, see Figure 1.

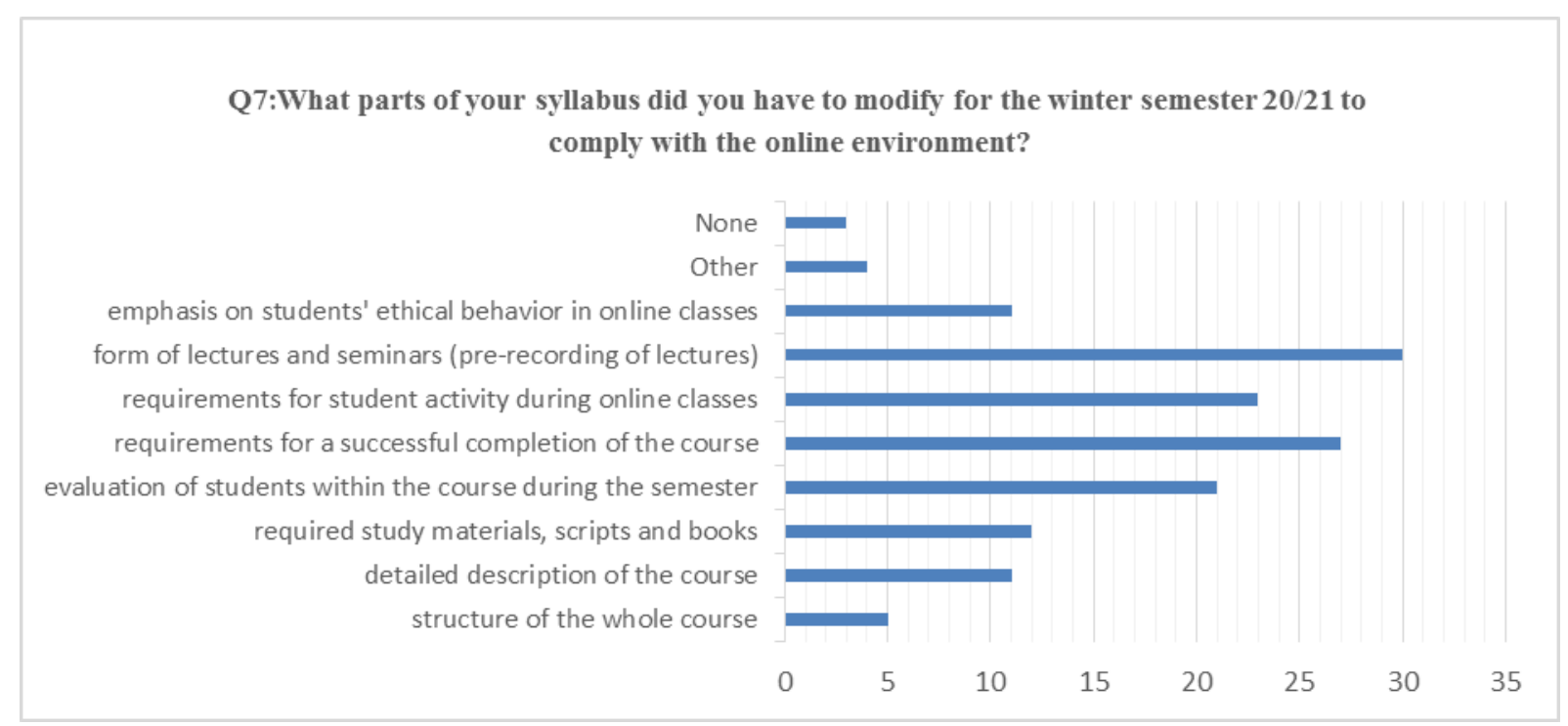

Source: Own calculation based on the questionnaire survey

Fig. 1: Syllabus modification during the winter semester 2020/21

This discrepancy may be connected with a different perception of the word syllabus in the Czech and English cultural context. When searching for the definition of syllabus in the Dictionary of Foreign Words, we find a very short definition "The syllabus is a study plan, 
brief keyword overview, excerpt, see [6]. English or American universities define a syllabus as not only a schedule of topics, readings, activities and assignments, but it should also include goals, objectives, or expected outcomes for the course, grading policies, procedure, and any other information necessary for students to succeed [7].

Nevertheless, referring to the questionnaire survey, it appears that for $85 \%$ of the respondents, a functional syllabus is clearly written and well organized. Furthermore, $57 \%$ of the respondents agree that it should contain precise requirements for passing the course and measurable evaluation of a student's performance during the course. On the other hand, only $38 \%$ of the teachers think the syllabus must deal with unethical behaviour or inappropriate conduct, such as cheating, during online lessons. Besides, Figure 1 revealed that a majority of teachers placed a big emphasis on the form of lectures and seminars to suit the online environment, especially pre-recording their lectures for students, 52\%. Not surprisingly, $47 \%$ had to modify conditions for successful completion of the course together with requirements for students' activity in an online class, $40 \%$. On the other hand, only $20 \%$ of the teachers made the course description more detailed, and only 19\% changed requirements for the ethical conduct of students in their online classes. When Cramér's V test was applied, there was found only weak dependence of the responses on the three determinants, i.e., sorting categories.

Questions 15 - 17 directed at the practical use of various tools in online classes. When asked whether the teachers had to exclude some materials or tasks commonly used in face-to-face teaching because they did not function in the online environment, it appeared that $36 \%$ of them had to make some changes in materials and $64 \%$ did not. Interestingly, when applying Cramér's V test, a moderate association, $\phi_{c}=0.482$, was found between the type of the faculty department and the response. For example, it appears that at the Department of Foreign Languages, 7 out of 9 teachers had to modify their tools, similarly at the Department of Marketing, 4 out of 8 teachers modified their tools for online teaching. Conversely, at the Department of Information Technologies, 2 teachers out of 8 modified their tools as well as at the Department of Statistics, 1 out of 6 teachers made significant changes. We suppose that this fact may be connected with the nature of a subject. Foreign languages and marketing are subjects where communication and interaction among students in the class are primarily necessary or desirable and this fact is reflected in online teaching more. In contrast, mathematical oriented and information technology subjects may still use conservative ways of teaching - programming, calculating etc. without much interaction.

Noteworthy replies were found when asked what specific tools the teachers had to exclude or, on the other hand, were helpful in online classes. Activities that did not work well in online teaching selected by teachers were discussion group work because of minimum student's interaction, drawing graphs and tables online, listening exercises in a group, brainstorming that eventually changed to brainwriting, which worked. Some teachers perceived sub-rooms where students could gather in smaller groups as inefficient.

On the other hand, there were many other activities and tools that the teachers recommended using. These were, for example, e-board instead of a standard board, sub-rooms for pair work, chats within Google meet, discussion forums, submitting tasks via google classroom, wiki in e-learning, web based tasks or feedback tests.

\subsection{Teacher - Students Online Class Interaction}

The following subsection discusses the academics' experience with online teaching, communication with students, their involvement, worries and expectations. Questions 18-28 directed at the work with various online tools, students' activity in online classes submitting 
their tasks, and enforcing the homework. The survey showed that students were not involved more in the online discussion and communication with the teachers than in regular classes. More than one third of the teachers sees no difference, and even $63 \%$ answered their students did not get involved in the discussion during online classes at all, the so-called 'dead souls'. One of the reasons given in the survey was the work with cameras, excuses on bad Internet connection or bad microphones. On the other hand, some teachers admitted that the attendance of online lectures was much higher than the attendance of regular lectures.

As to tasks assignment, only $34 \%$ of teachers made some changes. These mainly concerned modification tasks to Google meet environment, e-learning based tasks, online tests, using a lot more Internet sources and Internet-based tasks for a further discussion, collaborative writing and real-time email sharing, which could not be done in regular classes.

Questions 25 and 26 dealt with tasks enforcement. Surprisingly, only 17\% of the teachers modified conditions for submitting tasks online. Again, when applying Cramér's V test, a moderate association was found, $\phi_{c}=0.468$, between years of teaching experience and the type of response, see Figure 2. It means that the more the years or teaching experience, the more the teachers modified their task enforcement conditions for online teaching. The main responses included later task submitting, using chats to fulfil tasks, using e-learning to do the task online and specific deadline setting. The reason may lie in a better online preparation of junior colleagues, or the senior colleagues may react to a change more.

Finally, responses to question 28 related to online tasks evaluation showed that a mere $19 \%$ of the academic workers made some changes in the evaluation of online tasks. These included self-corrections of online tests, changing to multiple-choice tests and using Google Forms environment.

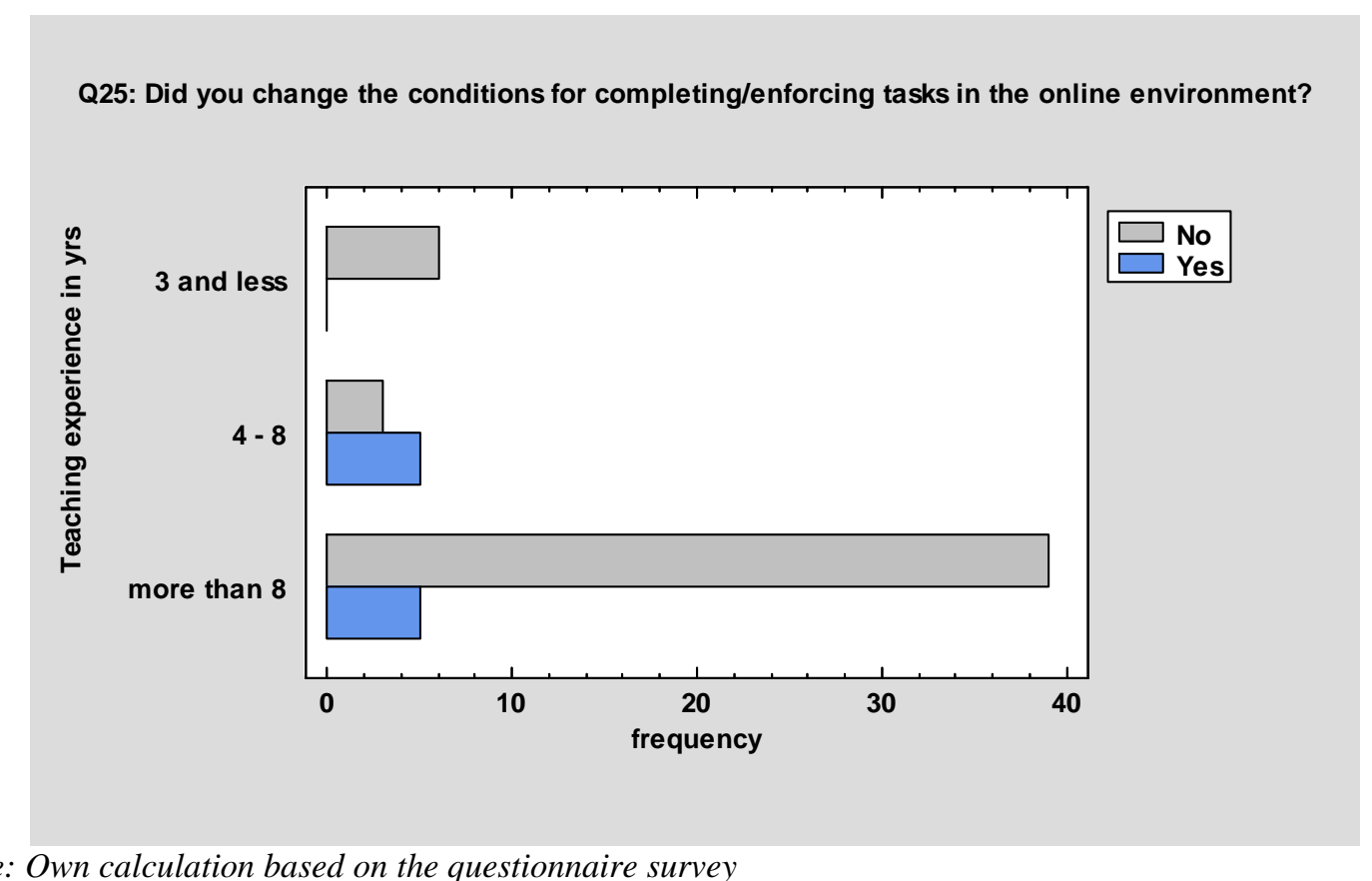

Source: Own calculation based on the questionnaire survey

Fig. 2: Moderate association between the years of experience and modifying conditions for completing the tasks online

\subsection{Attitude of the Teachers Towards Online Teaching - Feelings and Opinions}

The lack of direct interaction between students and teachers remains one of the biggest challenges that online education faces. Therefore, a final part of the questionnaire, questions $29-33$, addressed teachers' views, attitudes and experience with online teaching. The survey 
revealed that $22 \%$ of the teachers tend to be less strict in the final evaluation of students than in regular classes. When asked how and when the teachers provided students with the online support and consultations, the responses showed that $45 \%$ gave consultations individually by email, $26 \%$ on the exact date and time online and only $6 \%$ preferred face-to-face consultation at the faculty. The remaining $23 \%$ offered a combination of all the above possibilities including replies such as the response 'anytime, anywhere'. It is worth mentioning that when Cramér's V test was applied, a moderate association was found, $\phi_{c}=0.485$, between the status of a $\mathrm{PhD}$ student and the type of consultation and assistance. Figure 3 shows quite a notable fact that $\mathrm{PhD}$ students preferred only two types of consultations. Five $\mathrm{PhD}$ students gave consultations only by email and two $\mathrm{PhD}$ students preferred face-to-face consultations at school. It appears that the second most popular way of consultations, online consultations via Google meet, is rather preferable by other academic workers, $25 \%$.

Open question 30 attempted to find the most stressful moments during online classes for teachers. It is worth mentioning, but not surprising, that out of 58 responses, $24 \%$ of the teachers complained about limited communication and the absence of personal contact with students. They felt they were unable to communicate efficiently with their students in an online environment. The second largest group of teachers, $17 \%$ of the respondents, confirmed very high time-consuming preparation for online classes compared to regular classes. Finally, seven teachers reported zero feedback from students as their biggest concern along with the lack of 'energy charging' from their students. This opinion goes hand in hand with the statement of a few teachers that online teaching is an excellent addition to standard coursework, but it can never be a substitute, especially in teaching foreign languages. Notable replies also include a low concentration of students during online lessons, regular collapses of technology, dead souls, teachers mainly substituting psychologists and even the statement that online teaching is an unavoidable evil.

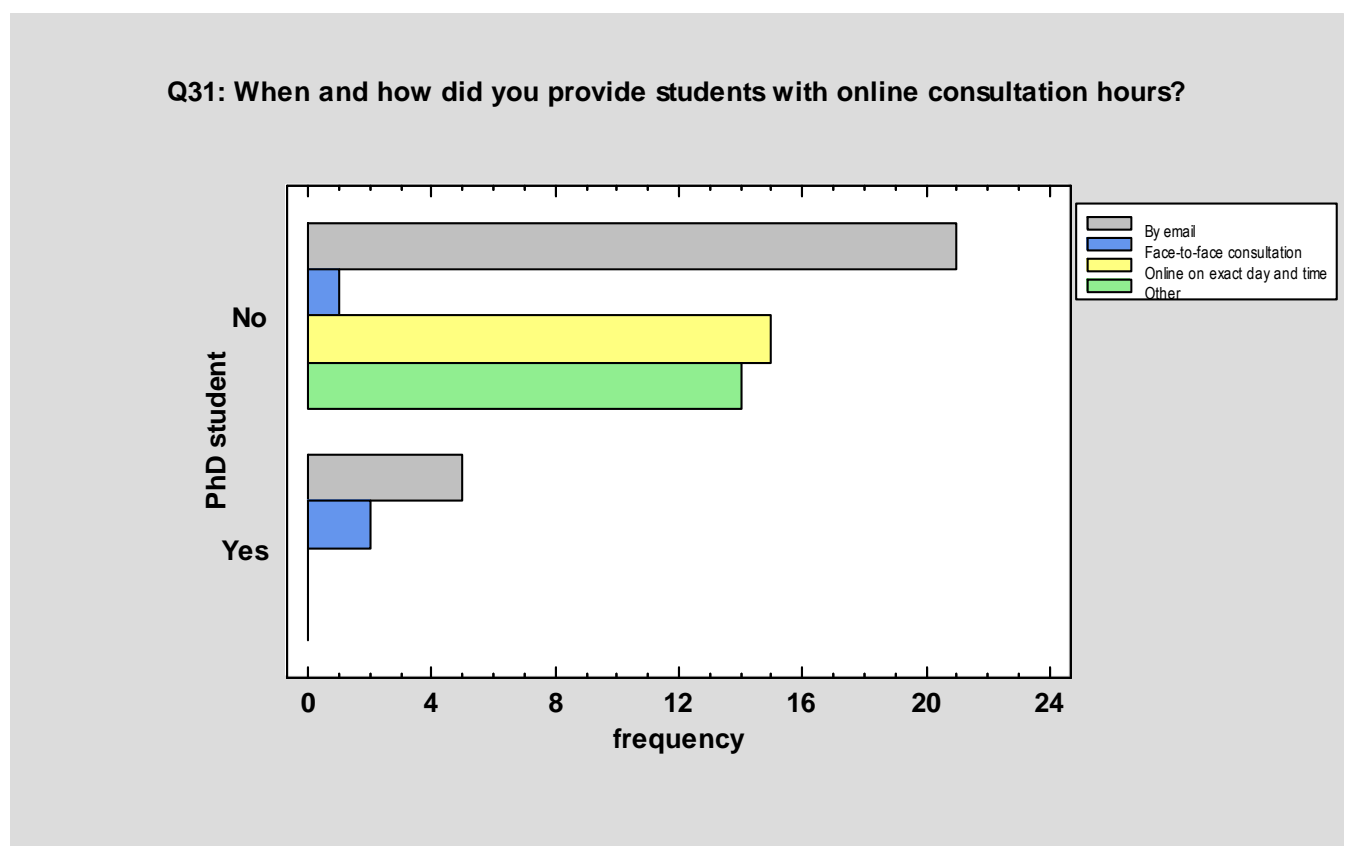

Source: Own calculation based on the questionnaire survey

Fig. 3: Moderate association between the status of a doctoral student and types

\section{Conclusion}

The main goal of the presented questionnaire survey was to find the academic workers' experience, opinions, and overall impact of online education during the coronavirus pandemic on their traditional teaching practises at the Faculty of Economics, Technical University of 
Liberec. The survey aimed at three areas of concern. These were possible syllabus modifications suitable for online teaching, teachers - students' interaction during online classes and open questions related to the teachers' feelings, concerns and attitudes towards online education.

At the beginning, the problem with the understanding of the word syllabus occurred. It seemed that every teacher had a different view of this term. Regardless of this discrepancy, however, the survey revealed that nearly half of the teachers made some changes in their regular syllabus to suit the online environment. Furthermore, it appeared that there were differences in approach among faculty departments. There is a relation between the subject and the modification. Subjects that include more communication and discussion strategies needed more modifications than subjects based on calculations and mathematics.

The survey also focused on inefficient and efficient online tools used in online classes. The teachers selected e-board, forums and chat rooms as the tools that function well in the online environment. On the other hand, most of them complained about a minimum interaction and limited students' involvement in the discussion within online classes.

Besides, there was found a moderate association between the years of teaching experience and enforcing tasks online. It appeared that the more years of experience, the more teachers modified their conditions for task enforcement during online education.

Finally, in online teaching, the teachers were mainly concerned about minimum interaction with their students, the absence of personal contact. They felt they were unable to communicate efficiently. There was also noted a lack of feedback from students. In their responses, the teachers also emphasized high time-consuming preparation time for online classes compared to regular classes.

To sum up, the survey showed that online teaching could be only supportive addition to standard courses; however, it can never substitute them completely.

\section{Literature}

[1] UNESCO: Education: From Disruption to Recovery. [online]. 2020. [accessed 2021-0804]. Available from WWW: https://en.unesco.org/covid19/educationresponse/

[2] BROWN, P. My virtual classroom. English Teaching Professional. May 2021, Issue 134, pp. 8-10. ISSN 1362-5276.

[3] SELVARAJ, A.; VISHNU, R.; NITHIN, K. A.; BENSON, N.; MATHEW, A. J.: Effect of pandemic based online education on teaching and learning system. International Journal of Educational Development. DOI: 10.1016/j.ijedudev.2021.102444

[4] HORTON, W.: E-learning by design. Pfeiffer San Francisco. 2006. ISBN13: 9780787984250.

[5] PALMER, M. S.; BACH. D. J.; STREIFER, A. C.: Measuring the Promise: A Learning-Focused Syllabus Rubric. To Improve the Academy: A Journal of Educational Development. 2014, Vol. 33, Issue 1, pp. 14-36. DOI: 10.1002/tia2.20004

[6] KLIMEŠ, L.: Slovník cizich slov. [The Dictionary of Foreign Words]. SPN, 2010. ISBN 978-80-7235-446-7.

[7] BAZYAR, Z.; DASTPAK, M.; TAGHINEZHAD, A.: Syllabus Design and Needs Analysis of Students in Educational System. Advances in Language and Literary Studies. 2015, Vol. 6, Issue 4. ISSN 2203-4714.

Mgr. Šárka Hastrdlová, Ph.D. 


\section{MODIFIKACE SYLABŮ NA EKONOMICKÉ FAKULTĚ TECHNICKÉ UNIVERZITY V LIBERCI BĚHEM ONLINE VÝUKY ZAP̌̌́ǏČINĚNÉ PANDEMIÍ - VÝSLEDKY DOTAZNÍKOVÉHO ŠETŘENÍ}

Článek shrnuje kvalitativní a kvantitativní analýzu výsledků dotazníkového šetření, které probíhalo na Ekonomické fakultě, Technické univerzity v Liberci v květnu 2021. Výjimečná situace, která nastala během pandemie koronaviru, donutila všechny akademické pracovníky přenést výuku do online prostředí. Je zřejmé, že takovýto přesun nutně musel způsobit změny nejen $\mathrm{v}$ charakteru výuky a sylabech, ale i v komunikaci se studenty i ve vztazích studentů a akademických pracovníků. Hlavním cílem tohoto výzkumu bylo tedy zjistit, jak, nebo zda, akademičtí pracovníci modifikovali své učební plány a přizpůsobili je výuce v online prostředí, a do jaké míry. Dotazník dále zkoumal názory učitelů na online výuku, její negativní a pozitivní stránky a na nástroje, které akademičtí pracovníci nejvíce, nebo naopak nejméně používali při online výuce. Výsledky výzkumu přinejmenším zmapovaly stávající situaci na Ekonomické fakultě a přinesly zamyšlení nad dalšími možnostmi, které online výuka nabízí a samozřejmě i nad jejími úskalími.

\section{MODIFIKATION DER SYLLABI AN DER ÖKONOMISCHEN FAKULTÄT DER TECHNISCHEN UNIVERSITÄT LIBEREC WÄHREND DES ONLINE-UNTERRICHTS ZU ZEITEN DER PANDEMIE - ERGEBNISSE DER FRAGEBOGENUNTERSUCHUNG}

Dieser Artikel beinhaltet eine qualitative und quantitative Analyse der Ergebnisse der Fragebogenuntersuchung, welche im Mai 2021 an der Ökonomischen Fakultät bei der Technischen Universität Liberec durchgeführt wurde. Die Ausnahmesituation, welche auf Grund der CoronaPandemie eingetreten ist, zwang alle akademischen Mitarbeiter zur Verlegung der Unterrichtsaktivität auf Online-Modus. Es ist offensichtlich, dass eine solche Verlagerung notwendigerweise Änderungen nicht nur im Charakter des Unterrichts und der Syllabi, sondern auch sowohl in der Kommunikation mit den Studenten als auch in der Beziehung zwischen Studenten und Lehrpersonal nach sich ziehen. Das Hauptziel dieser Studie liegt darin festzustellen, wie, ob bzw. in welchem Maß die akademischen Mitarbeiter ihre Lehrpläne modifiziert und sie dem Online-Unterricht angeglichen haben. Der Fragebogen erforschte weiterhin die Meinungen der Lehrer zum Online-Unterricht, dessen negative und positive Seiten sowie zu den Hilfsmitteln, welche das Lehrpersonal am meisten oder am wenigsten beim Online-Unterricht verwendet haben. Die Ergebnisse dieser Untersuchung zeigen ein Bild der bestehenden Situation an der Ökonomischen Fakultät und regen an zum Nachdenken über die weiteren Möglichkeiten, welche der Online-Unterricht bietet, und natürlich auch über dessen Tücken.

\section{MODYFIKACJA SYLABUSÓW NA WYDZIALE EKONOMII UNIWERSYTETU TECHNICZNEGO W LIBERCU PODCZAS ZAJĘĆ ONLINE SPOWODOWANYCH PANDEMIĄ - WYNIKI BADAŃ ANKIETOWYCH}

W artykule podsumowano analizę jakościową i ilościową wyników badań ankietowych, które przeprowadzono na Wydziale Ekonomii Uniwersytetu Technicznego w Libercu w maju 2021 roku. Wyjątkowa sytuacja, która nastąpiła w trakcie pandemii koronawirusa, zmusiła wszystkich pracowników akademickich do przeniesienia zajęć do środowiska online. Oczywiste jest, że takie przeniesienie musiało spowodować zmiany nie tylko w charakterze zajęć i sylabusach, ale także w komunikacji ze studentami oraz relacjach studentów i pracowników akademickich. Głównym celem przeprowadzonych badań było ustalenie, jak lub czy pracownicy akademiccy zmodyfikowali swoje plany nauczania i dostosowali je do nauczania w środowisku online oraz w jakim stopniu. W ramach ankiety badano także opinie nauczycieli na temat zajęć online, ich negatywne i pozytywne strony oraz narzędzia, $\mathrm{z}$ jakich pracownicy akademiccy najbardziej lub, przeciwnie, najmniej korzystali w nauczaniu online. Wyniki badań przedstawiają istniejącą sytuację na Wydziale Ekonomii a także są podstawą do zastanowienia się nad innymi możliwościami, jakie daje nauczanie online a także nad jego mankamentami. 